\title{
THREE CASES OF RETINITIS PSEUDO-NEPHRITICA STELLATA. CONSIDERATIONS ON THE PATHOGENESIS OF NEURORETINITIS IN GENERAL
}

\author{
BY
}

\author{
Prof. Dr. Elena Puscariu and Dr. Julius Nitzulescu \\ FROM THE OPHTHALMOLOGICAL CLINICS AT JASSY (ROUMANIA) \\ DIRECTOR: PROF. ELENA PUSCARIU
}

IN a previous paper we have discussed the different explanations proposed for the pathogenesis of so-called retinitis albuminurica. Based on 19 personal observations, we have adopted the opinion that the disease should be called the neuro-retinitis of Bright's disease, in order to point out first the constancy with which the papillary lesions are found and secondly that there is not such causal relationship between retinitis and nephritis as the usual name would seem to imply. In fact Bright's disease seems to be not a simple kidney process, but a more general metabolic disturbance touching at the same time, independently, kidney, retina and other territories in the body.

The discussion about this problem has continued actively during the last few years and although the most authoritative opinions are pretty close, a real understanding of the pathogenic mechanism is yet wanting.

The older theories which tried to identify different toxic products, accumulating in the body as a result of kidney insufficiency, and causing the retinitis, could not be verified. The most popular were those of Widal (azothaemia) and of Chauffard (cholesterinaemia). In the same line Poyales has recently pointed once more to the hypercreatininaemia.

The most authoritative workers, however, tend to-day to admit the direct, immediate influence of local circulatory troubles in the production of the retinal lesions. That such troubles are themselves due to some toxic influence, of renal or general origin, remains very probably true, and we shall return to that point later on.

But if these all admit a vascular disease, they are far from admitting the same causal mechanism. We could divide into two classes the explanations given for a vascular origin of neuroretinitis, one considering the necessity of a real vascular lesion, which precedes the parenchymal process, the other admitting the existence of simple functional troubles, which are followed as a result, by parenchymal and vascular lesions.

v. Michel has admitted since 1899 , a causal relationship between arteriosclerosis and retinitis. Vascular lesions (contraction, sinuosities, sclerosis) are usually found on ophthalmoscopic 
examination. Recently, Wagener in 81 cases of neuroretinitis has seen 21 which had a normal kidney function (25 per cent.) while only six showed a normal arterial appearance. In fact, these vascular lesions are not seen in every case. Leber even, objected to $\mathrm{v}$. Michel's theory, the absence of any correspondence between the retinal and the general arteriosclerosis, considering the first rather as a result of the disease than as a cause. He pointed out also, the lack of parallelism between the territories of distribution in the retina, of the sclerosis and the parenchymal lesions. In his report to the French Ophthalmological Congress in 1912, RochonDuvigneaud concluded against the arteriosclerotic theory. Recently, Kalt has published a new observation of neuroretinitis, in which he could not demonstrate any arterial lesion.

Such objections are avoided by those who admit that retinitis is due to a simple functional circulatory trouble, in connection with local or general hypertension. The importance of hypertension cannot easily be overlooked, because it appears to be one of the most frequent symptoms associated with neuroretinitis. Among our own observations we have met it 24 times in 29 cases. The same conclusion appears from larger statistics. (Wagener, Kollert.) Kollert in 85 cases found only three without hypertension, and eight where it was inconstant. He believes that in such cases, where one does not find actual hypertension, it must have previously existed at the moment of appearance of the disease. Spalding and Curtis, in a large number of cases, concluded that hypertension plays a great part in the genesis of retinitis diabetica. But how should hypertension produce the retinal appearances?

Leber thought that hypertension was due to a general peripheral arteriolar contraction and that the ischaemia resulting in the retinal territory was the cause of the lesions. Recently, Volhard admitted the same ischaemia as due to spasmodic vascular contraction (malignant hypertension). Such ischaemia would bring an insufficient oxygen supply, and consecutively nutritional troubles in the parenchymal tissues and the arterial walls, resulting in arteritis and retinitis.

But Volhard's spasmodic contractions are not usually seen. They are more frequently encountered in eclamptic neuroretinitis (Myllius). Most authors would not give to them a general importance. (Lo Cascio, Aschof, Schieck, Fahr). Hansen calls attention to the fact that sometimes an appearance of arterial contraction can be produced by retinal oedema, hiding the vessel. The majority of authors admit, therefore, that hypertension produces the neuroretinitis, through hyperaemia and stasis with the same result of anoxaemia and nutritional troubles (Schieck). Some authors are more reserved in admitting the causal action of hyper- 
tension. (Chabanier, Charlin, Barlow.). In our own cases we could not find it always. Should we admit in such circumstances Kollert's view that hypertension had existed previously and had disappeared? Another possibility still remains, in admitting the action of local arterial hypertension. Bailliart tends to such an hypothesis. He recognizes (as does Morax) that local vascular trouble is at the basis of neuroretinitis, even when no arterial. lesions can be demonstrated. This should primarily be a local hypertension which seems still higher than the value corresponding to the general arterial hypertension.

Anyhow the nature of the signs of neuroretinitis (haemorrhages, exudation), shows the direct participation of the circulatory troubles. The recent observations of De La Fontaine Vervey, tend to give a new support to those who admit the existence of arterial lesions. He made histological 'examinations of 23 eyes belonging to patients with atherosclerosis, among whom three had neuroretinitis. By means of special methods, he found a fine lipoid and protein infiltration of the walls of retinal arterioles, which would have escaped a more superficial examination. The interesting fact is that De La Fontaine Vervey did not find such lesions in retinal arteries, other than those belonging to the neuroretinitis cases. In all other cases the retinal arterioles were healthy, though the other arterioles (kidney, brain) were affected. The retinal arterioles would seem then, somewhat better protected against sclerosis and would yield only to stronger baneful influences. Such facts would explain the usual bad prognosis of neuroretinitis.

A new point of view is given by Koyanagi who points out the importance of choroidal vascular lesions. In an early case, he has found, by serial sections, that the branches of the central artery were healthy, whilst only the choroidal vessels showed sclerosis, corresponding to the territories of retinal lesions. This fact should explain why sometimes the retinal arteries are found healthy (as in Kalt's observation), if no serious examination of the choroidal vessels was made.

The next question to answer is, to what process is this circulatory trouble due? The French school in general, even admitting the rôle of vascular lesions, subordinates it to the pre-existing nephritis. Bailliart says: "All in retinitis albuminurica is subordinated to the kidney insufficiency; the circulatory trouble itself, if it is precocious is not primitive." In the same way, Leber considered hypertension as due to nephritis. Ambard and Yolande Levy seem to admit an association of renal insufficiency, with general hypertension. The German school, and, in France, Chabanier, and recently 'Terrien, consider the neuroretinitis independent of the kidney disease, having only an evolution parallel with it, and going on under the influence of common 
causes. This was also the opinion that we had adopted in our previous paper. Kahler and Sallmann, suppose the existence of a special nervous centre of hypertension, which is susceptible to the different toxic substances of renal or other origin. Such a centre would be primarily influenced in the progression of the metabolic disturbances which characterize Bright's disease, and - once the hypertension were produced, the local ocular or renal lesions would follow as a consequence. (Horniker, Schieck.)

Terrien and Renard in their recent paper, read at the Amsterdam Congress, conclude that "the ophthalmoscopic appearance of the so-called Bright's neuroretinitis seems to be produced by the association of multiple factors which produce a deep disturbance of the general state, manifested most frequently by hypertension and modification in the composition of the serum (lipoids, urea, etc.) These factors will produce in the eye vascular lesions, and perhaps due to those, or only in parallel with them, exudative changes. Excepting these, other special lesions will evolve at same time with the ocular lesions (especially kidney lesions)."

As pointed out previously our experience brings us to admit the existence of circulatory troubles in the genesis of Bright's neuroretinitis, independent of kidney insufficiency, and even of general hypertension. We think that the rare observations of the socalled retinitis pseudonephritica stellata, can bring a particular contribution for the understanding of these still undecided conditions. Having recently had the opportunity of seeing three such cases, we think it of interest to publish them, and to point out the suggestions which they may furnish. Our cases are as follows :-

Case I.-The wife of a peasant, aged 32 years, entered the clinic on March 10, 1929. No definite history of note before the actual disease began in June, 1928, with headaches coming in bouts of 20-60 minutes, which ended with vomiting, provoked sometimes by the patient herself, in order to put an end to her suffering. She had some drowsiness and more rarely faintings. Treatment had not brought any improvement. Last autumn she began to notice obscuration of sight and for the past two weeks she has become completely blind.

On examination she had no perception of light. The pupils were of equal width $(6 \mathrm{~mm}$.) Tn., R. E. $=12 \mathrm{~mm}$. L. E. $=15 \mathrm{~mm}$. Ophthalmoscopic examination: R.E. The papilla seemed enlarged with oedematous pinkish appearance and greyish borders. The retina around the papilla was discoloured and speckled with numerous haemorrhages of varying size, which in places hid the vessels. L. E.-The borders of the papilla were indefinite, disappearing into a striated greyish retina, speckled with less numerous haemorrhages. The papilla was marbled with spots, 
pink or pale. The vessels were veiled in its centre. The macula presented fine striations directed towards the papilla and reaching nearly to its border. (The image of a half-star.)

The knee-jerks were diminished. Babinski negative. The signs of Trousseau and Weiss were positive. Sensation was normal. The gait was difficult, zig-zag-like, with some tendency to staggering. C. S. F., tension 45-50.mm. (Claude.) Blood Wassermann, negative. Pandy, Nonne Appelt, slightly positive. The benzocolloidal reaction negative. No lymphocytes. Albumin, 0.45 per cent. Urine: sp. gr., 1036. Chlorides 7 per cent. Urea 18 per cent. No albumin or sugar. Blood urea, 0.026 per cent. Cholesterol, 0.167 per cent. Calcium, 0.010 mgr. per cent. Chlorides, 0.620 per cent. Kidney function (Volhard) normal. General arterial tension 11/8. Retinal arterial tension 75/50. On one side, in the dorsal region, was a tumour, the size of a small orange, having a firm consistency and no very definite limits, fixed to the deep tissues. without adhering to the skin. A biopsy showed it to be situated under the muscular layer and to be very vascular. The excised fragment was pinkish-grey and showed on microscopic examination the structure of an adeno-carcinoma with groups of glandular acini, having one or two layers of vacuolated cells. In some places the constitution was frankly carcinomatous. No lesions could be detected in the genito-urinary tract, or in the mammae.

Case II.-A girl, aged 11 years, entered the clinic on November 21,1929 . The father died two weeks before the birth of the child, with pulmonary tuberculosis. The mother is healthy. She has another child, who is healthy, and has had no miscarriages. The patient has had measles and suffers frequently from colds and influenza. The general state was pretty good. Last summer she had an attack of malaria. On November 13 she observed an impairment of the sight of the left eye and this has since progressively diminished. No headaches. The body temperature has varied between $37 \cdot 2^{\circ}$ and $37 \cdot 8^{\circ} \mathrm{C}$.

On examination, R. V. $=1, \mathrm{~L} . \mathrm{V} .=$ counts fingers at $30 \mathrm{~cm}$. Ophthalmoscopic examination: L. E. The papilla was enlarged. pale yellowish with borders totally hidden. The vessels veiled at their emergence. The lower half of the papilla seemed swollen. Fine vascular branches appeared interrupted at the borders of the papilla, and then followed a sinuous course. On the external lower part of the macula some fine striation, having the disposition of a macular star, was present, with fine, yellowish, interrupted branches, reaching nearly to the border of the papilla. A small haemorrhage was situated between the star and the papilla. Nothing else to notice in the rest of the retina. The visual field showed a central scotoma.

General state :-Well grown, pale, presenting evident traces of 
thoracic rickets. The left groin glands were swollen. On examination of the respiratory apparatus, the only thing to notice was the sign of D'Espine, which was frankly positive. The sinuses, frontal and maxillary were normal. Hypertrophic rhinitis on the left side. Hypertrophy of the Waldayer lymphoid circle. Persistence of the left temporary canine tooth, which has brought a vicious implantation of the permanent one: caries of the last left molar. The blood Wassermann reaction was negative. The intradermal reaction with tuberculin $(1 / 10,000)$, negative. X-ray examination showed a marking of the hilar regions, with congestive reaction, especially on the right side. The parenchyma was clear. Laboratory examination: Urine: No albumin, no sugar, no casts. Ambard's ureosecretory constant $0 \cdot 08$. Blood examination: Neutrophile polymorphonuclear cells, 58 per cent., eosinophile cells, 4 per cent., mononuclear cells, 18 per cent., lymphocytes, 19 per cent., myelocytes, 1 per cent., transition forms, 3 per cent. Treatment : Injections with 0.50 urotropin daily, genostrychnine, phospharsyl, ultra-violet irradiation. Treatment of the nose and pharynx by specialist. On November 13 the papilla began to have a clearer delimitation, but still presented in the lower quarter the oedematous appearance. By December 8, the tumefaction had disappeared, the borders were clearer. The star was less. pronounced, with fewer rays and more interrupted. The visual acuity increased to $1 / 3$. The central scotoma was much reduced. The left papilla was pale with hazy edge and veiled vessels, which became apparent outside the disc. A group of white spots with sharp outline and the size of a pin's head, or smaller was seen near the inferior part of the papilla. Two white nodules were present near the superior edge. The macula half star still persisted. Small groups of pale points spread in the inferior part of the peripapillary retina.

Case 11I.-A male peasant, aged 41 years, entered the clinic on January 13, 1929, for diminution of the sight of the left eye, observed during the past 12 days. He is married, has healthy children, does not smoke or drink. Has had diphtheria in childhood.

On examination, R. V. $=0 \cdot 4, \mathrm{~L} . \mathrm{V}$. counts fingers at $10 \mathrm{~cm}$. Ophthalmoscopic examination: R. E. nothing abnormal. L. E. The borders of the papilla and the peripapillary retina were striated and greyish. The centre of the papilla was more coloured, the emergence of the vessels totally veiled, the vascular branches appeared at the border of the disc. The two superior branches disappeared under a white spot, of medium size, situated near the superior border of the papilla. From that spot the vessels continued distended and sinuous. In the inferior part, there was another white spot, covering a vessel which emerged from the border of the 
papilla. Well formed macular star, with numerous pale, long, branches. The branches were less numerous on the external side. The visual field presented a slight narrowing to the right. To the left, the patient recognized the colours only at the fixation point. The retinal arterial tension $75 / 25 \mathrm{~mm}$. The serodiagnostic blood Wassermann reaction, negative. General arterial tension 15/7. No cardiac or pulse abnormality. Azothaemia, 0.042 , cholesterol, 0.10 per cent. Urine, no sugar, no albumin, urea $2 \cdot 4 \mathrm{gr}$. per cent. uric acid, 0.026 per cent., kidney permeability (Volhardt) normal C. S. F., tension $4 \tau \mathrm{mm}$. (Claude.) Lymphocytes 4.5 per c.mm. Nonne Appelt, negative, albumin, 0.022 per cent.

The patient was treated with strychnine. Subsequent course : January 27,1929, L. V., 0.2 . Visual field for white from $40^{\circ}$ to $30^{\circ}$ and for colours from $30^{\circ}$ to $15^{\circ}$. He left the clinic and returned on March 20. R.V. $=0 \cdot 4, \mathrm{~L} . \mathrm{V} .=0 \cdot 3$. We then found retinal lesions on the right side as well. The papilla was striated on the temporal side with borders more red and less regular than in the rest. The papillary and macular region were occupied by small white bright spots. In the left eye the appearance was unchanged. Visual field normal in the right, narrowed in the left eye. He continues to have no other general trouble except the retinitis.

The patient from the first observation had signs of intracranial hypertension and a tumour adherent to the ribs, of adenocarcinomatous constitution, very probably of metastatic origin. It is therefore possible that the intracranial hypertension might have been due to a cerebral metastasis and we could place this case in the same category as those published by Colrat, where a retinitis pseudonephritica had appeared during the evolution of cerebral tumours. Before Colrat, Paton and Holmes have spoken of a macular form appearing sometimes with papillary tumour oedema. On the other hand, Pick has described as "retinitis cachecticorum," lesions appearing in the retinae of cachectic patients, especially carcinomatous, and showing haemorrhages and white spots. In his cases the anaemia was extreme.

L. Werner also has observed a girl, aged 24 years, suffering from chlorosis, who had unilateral neuroretinitis with papillary and peripapillary oedema and macular star. Another such case was published by Augstein.

Case $\Pi$ could be put down to a local tuberculosis (although the negative intradermal reaction would be against this diagnosis). Recently, Kaminskij saw a case of neuroretinitis, with unilateral star, no renal lesions, but coexisting with pulmonary tuberculosis, which was proved by tuberculin treatment. In the observations published by Kleiber, the papillary and peripapillary oedema and haemorrhages were coincident with a choroidal focus and with a 
typical star. Kidneys and arterial tension were normal and only a tuberculin reaction justified a diagnosis of a tuberculous process. Presence of stars in periphlebitis retinae tuberculosa has been observed by Sydler Huguenin and Schieck.

The cases of neuroretinitis stellata pseudonephritica, appearing after an infectious disease are still more frequent. Epidemics of influenza have given a specially large number of cases. Danco quotes the observations of Leber, Hartridge-Gross and Maclakof, and gives the history of one case of his own, with neuritis, exudates and macular star, coinciding with normal kidney function. The arterial tension was only $120 \mathrm{~mm}$. but a slight rachidian hypertension thought to be due to meningitis serosa was present. This case was recently seen again by Hessberg (discussion in Stewens's paper) who found optic atrophy developing. We could compare it with our third observation, where we have found also intrarachidian hypertension.

Stewens has published an observation of bilateral neuroretinitis with macular star appearing five days after measles, with a normal kidney function, but a transient hypertension $115 / 60$ (at the age of 6 years) becoming after three days $95 / 60$. Various retinal lesions have in fact been observed, following measles.

$\mathrm{R}$. Onfray has had a case of unilateral neuroretinitis with normal kidney function which was improved by antiluetic treatment.

Junius, in a series of four observations, which he collects under the name of "retinitis exudativa juvenilis," has one with the presence of bilateral macular star. This was a woman who was under observation from the age of 14 years to 40 , when she died, with an aortic aneurysm. Although the Wassermann reaction had been negative, the author questions if the aetiological factor was not hereditary syphilis. The kidney and the arterial tension were normal. The ocular lesions later retrogressed.

Pseudonephritic neuroretinitis with macular star has been described also by Coppez (unilateral lesion connected perhaps with bad teeth); by Pascheff (no precise aetiology); by.Schieck (Korsakow's syndrome). Nitsch had a case appearing after a cranial trauma, with hemiparesis and aphasia.

Magitot has seen a case where typical retinal lesions appeared in immediate connection with slight corneal trauma. The sight diminished immediately. Examination made 17 days after the accident showed the characteristic exudates, papillary oedema and star, coinciding with a normal general state. The signs disappeared totally after six months. Of course, it is not certain that the ocular lesions were not there before the trauma, which gave rise to. an ophthalmoscopic examination. Magitot inclines to attribute the cause to the trauma.

Notwithstanding the diversity of aetiological factors, all these 
observations present a common ophthalmoscopic image, and evolution with a relatively mild prognosis, absolute independence of any renal lesion and of general arterial disease. At the same time, the presence of a macular star similar to that found in the course of a Bright's neuroretinitis inclined Leber to create a special entity, the retinitis pseudo-albuminurica stellata. In fact, the presence of the macular star in the course of Bright's neuroretinitis is very inconstant. We have met it three times in our total of 35 observed cases. On the contrary, as Schieck points out, the star is found much more frequently in the pseudonephritic forms, and is due to the particular disposition imposed on the exudates by the radiate architecture of the perifoveal region.

On the other hand, such cases if they have the local symptomatic appearance of a Bright's neuroretinitis, do not have any nephritis or hypertension. Should we admit then that the same ophthalmoscopic image is due in both cases to two different mechanisms? That is why Schieck doubts if in the cases of pseudonephritic neuroretinitis, which have been previously published, and where no mention about arterial tension was made, this last could not have been the causal factor. But our present observations and some others (Kleiber, Junius, Danco), where the blood pressure was measured, showed it to be normal.

The neuroretinitis pseudonephritica stellata becomes still more interesting if we consider it (as Junius does), as a transition form between typical nephritic neuroretinitis and the different forms of central exudative retinitis which show a more variable fundus picture.

Transition towards the typical Bright's forms could be found in some of the cases of Pick (neuroretinitis in cachectics). In these, besides the typical ocular symptoms, the clinical appearance suggested the existence of a kidney lesion, but the necropsy showed the total absence of such leșions and only a simple oedematous congestion. Just the same occurred in a case of Marx and Hellmuth. 'The evidence of kidney participation comprised albuminuria and casts, appearing only after physical exertion, with an insufficient response to the water test. The author attributes these signs not to the nephritis but to a general disease of the endotheliocapillary system.

In Bakker's case, a unilateral retinitis with oedema, haemorrhages and star, was co-incident with a normal circulatory system, and only traces of albumen in the urine. In this case too one should think rather of direct action of influenza toxin on the retina. Still more doubtful was the nephritis in a case of Farnarier, which besides the typical ocular signs had an azothemia of 0.3 only in one determination and was considered by the author as transient. 
Another group in this transition series is formed by the cases where we have the picture of neuroretinitis but without any star. Such is Pick's fifth case where the condition had appeared in a woman with grave carcinomatous anaemia. Nageldinger has observed a bilateral neuroretinitis with cyclitis, following on influenza. Well studied is also the case of Menacho where a typical ocular picture was co-incident with normal blood, urine and arterial tension, and a negative Wassermann reaction.

Then at the other extremity of the series we can consider the four observations of Junius, which he calls " retinitis exudativa juvenilis." One case had a macular star and was at first considered as the pseudonephritic form of Leber. All three others had a more variable appearance, characterized in general by exudative spots of different size and various distribution, accompanied by haemorrhages and papillary lesions. Junius compares his observations with those of pseudonephritic neuroretinitis of Augstein and Danco, which he considers to be of the same nature. "Each of these observations gives a particular characteristic to the picture of the disease. But all have in common a related clinical picture, which, although variable in its appearance, is due to vascular circulatory lesions in the small vessels, which have an essential importance for the life of the macula."

Such exudative changes have been observed also in cases of the neuroretinitis of Bright's disease. So we could consider the observation of De Logu where coincidently with renal trouble, urinary casts, aortic reflux and cardiac hypertrophy, there was a picture of Bright's neuroretinitis in one eye and one of retinitis circinata, with white spots disposed as a horse-shoe around the macula, in the other eye. There were some haemorrhages in this eye and the spots were situated beneath the vessels.

We could consider Horniker's eight cases in the same group. He collected these under the name of "retinitis centralis of vasomotor origin." In them the ophthalmoscopic image presented haemorrhages, oedema, and small whitish foci, and at the same time a contraction of the fine macular vessels attributed to a capillary spasm.

In conclusion all these forms have in common the presence of white spots of different sizes, localized in the posterior pole and accompanying the papillary lesions, the haemorrhages and sometimes, even choroidal lesions. Another characteristic fact is the tendency to resorption, which in fact belongs in certain conditions also to the spots of the typical neuroretinitis of Bright's disease.

Should we consider the exudates of Bright's neuroretinitis as being of a different nature? We distinguish in this disease two kinds of white spots. The one is due to a local degenerative gangliform tumefaction of the nerve fibres. Such lesions have 
been met with not only in the retina, but also in the posterior roots of the spinal cord, in the course of various affections. (Roth, Minich.) Such are retinitis pigmentosa, retinitis cachectichorum, lues, sepsis and brain diseases, for the retina; pernicious and bothriocephalus anaemia for the cord. Minich admits that blood changes and spinal changes have the same origin, from the production of toxic substances. Roth considers the retinal varicose hypertrophy of nerve fibres as the expression of an inflammatory process.

Other white spots are of exudative origin and the majority of authors consider them of vascular origin. We have seen that the tendency is to attribute to arterial hypertension the predominant rôle in their production.

In quite a number of the cases previously recorded a simple local vascular process of toxic origin could be admitted. Such are the cases in the course of carcinomatous anaemia. One could not speak in these instances of hypertension. On the other hand fundus. lesions have been observed in the course of essential pernicious anaemia (described more recently by Fileti), but they do not have the characteristic exudative form as in Pick cases. For an explanation of the latter, we should be inclined to admit, in accordance with Pick, a local toxic action due to the progress of the carcinomatous process. Perhaps in the cases with luetic and tuberculous origin the same explanation might be true.

Should we, as Bailliart does, accord more importance to the local arterial tension and explain the genesis of neuroretinitis on the basis of purely functional, circulatory troubles? Bailliart has found in Bright's neuroretinitis the retinal arterial tension increased in a greater proportion, than we should expect from the general hypertension. One could easily imagine cases where only the retinal tension should increase, with a normal general tension. Such could be the genesis of neuroretinitis in the course of cerebral tumours and perhaps of those of periphlebitis retinae tuberculosa. Intrarachidian hypertension could play a part also in the genesis of the local circulatory trouble. Danco's patient showed it, perhaps the case of Nitsch (which followed cerebral trauma) belongs to the same class. Two of our three patients had hypertension of the cerebro-spinal fluid but the retinal arterial tension at the moment of our examination was respectively $75 / 50$, and $75 / 25$.

There is, however, no necessity to admit local hypertension as a rule. Foster Moore and Duke-Elder,* think that the retinal capillaries, if perfectly healthy, should resist variations of

- W. Stewart Duke-Elder.-Recent Advances in Ophthalmology. Second Edition, p. 240. London : J. \& A. Churchill. 1929. 
pressure without any leakage. "The very essence of retinal haemorrhages is probably capillary dysfunction rather than high blood pressure itself . . . Haemorrhages, together with exudates, are the result of injurious processes affecting their walls, or are an expression of defective circulation through them so that their endothelium is impaired." According to these authors the primary cause remains thus only an endothelial impairment, be it due to circulating deleterious toxins, or when arteriosclerosis complicates the picture, to an insufficient blood supply, adding its effect to the suffering endothelium.

There is, however, a particular class of case in which we must admit that the beginning of the lesions is the result of a simple mechanical defect of the circulation. These are the cases of pseudoalbuminuric retinitis appearing during the evolution of an intracranial tumour. We cannot discuss here the very complex problem of papillary stasis. Leber admitted once an inflammatory pathogenesis. Some authors saw in it vasomotor troubles. Recently Magitot considers papillary oedema as a result of a defect in the functions of the capillary walls. But the majority of authors will admit to-day a mechanical pathogenesis as a result of an increased intracranial pressure. The authors differ in their explanation as how the intracranial pressure will produce a papillary stasis. Paton and Holmes have admitted that intracranial pressure transmitted to the optic nerve sheath produces simultaneously the increase of pressure in the central vein and a stasis in the lymphatic circulation. Only by the association of these two causes should a papillary stasis result. Schieck, Behr Lewinsohn, Abelsdorf, although admitting somewhat different mechanisms accept in fact the compression lymph stagnation. This theory can explain at best the papillary oedema associated with high intracranial pressure (tumours, abscesses), eventually serous meningitis, although in the latter, an inflammatory process could perhaps play a part. Some will admit that any papillary vedema, even that of Bright's neuroretinitis is always due to a high intracranial pressure and produced in the same way. Paton and Holmes distinguish sharply between the mechanical lesions due to tumour hypertension and the inflammatory process seen in nephritis or arteriosclerosis. Behr speaks in such cases of an active lymph stasis due to a real transudation of lymph through disturbed capillary walls. A All admit that during the evolution of the disease, inflammatory reactions of the tissues add themselves to the previous mechanical distension of the tumour papillary stasis.

Now, should we admit that the pathogenesis of the clinical aspects which simulate a Bright's neuroretinitis is different in the case of cerebral tumours from what it is in the other cases? 
We tend to accept the mechanical " primum movens" in the production of tumour stasis, but as Schieck has pointed out, and as Volhard has admitted, in his theory of capillary spasm and retinal ischaemia, such circulatory trouble could not last without bringing local nutritional troubles and consecutive lesions to impose themselves on the simple initial picture.

In what concerns the exudative forms of retinitis (Bright's or pseudo-Bright's), we tend to admit the so-called inflammatory theory (taking the word inflammation in a broad sense) as discussed previously in this paper. In the case of tumour neuroretinitis the " primum movens" might be a mechanical one. But no matter what the "primum movens" might be, the so-called inflammatory process, the reaction on the part of vessels and retina must appear and contribute to the clinical picture of neuroretinitis.

Paton and Holmes themselves point out that in some cases a clinical differentiation between these two syndromes becomes impossible. Thus, the local lesions constituting the clinical syndrome can have their origin in general, metabolic, toxic disturbances (case of Brightism) or at other times, in the special conditions which follow local metabolic troubles, resulting from the mechanical action of the tumour stasis. But their evolution remains related just as their clinical pictures which can sometimes be confused.

The theories which tend to explain the production of the retinal lesions must consider also the fact of their localization at the posterior pole of the globe. Schieck explains this on a functional basis. In view of the fact that we do not find in the central portions of the retina a greater ramification of vessels than in the rest of it, although the physiological activity is much greater, one should admit that even in normal conditions, the walls of the arterioles which are situated in that portion must satisfy such increased activity by an increase of permeability. Immediately the equilibrium of pressure between the content of the vessels and their exterior is changed as a result of hypertension, this will be the territory where the first exudation will take place.

Schieck quotes the observation of Bartels, where the neuroretinitis appeared unilaterally while the other eye, aphakic for some years and amblyopic, remained without signs of retinitis. So should we explain also the observation of Greeff,where the signs of neuroretinitis disappeared when an attack of glaucoma occurred.

Koyanagi sees the central localization of the lesions, as a localization in the territory corresponding to the choroidal lesions, in the portion where the capillary net, which is important for the nutrition of the retina, is especially close-meshed. 
In fact, the analysis of the cases related in this paper brings us to the same conclusions as others have found, that for the cause of the characteristic white spots and oedema, there is not of necessity any nephritis, or even a general hypertension. But admitting the rôle of the local circulatory trouble, we are still far from a full explanation of the pathogenesis. Bailliart questions why from all the retinal transudations and haemorrhages (the oedema of traumatic commotio for instance) which are so easily resorbed, only those of Bright's neuroretinitis (or we should say all retinal exudative forms), give persisting deposits. Admitting the rôle and origin of fibrin, as it was described by R. Duvigneaud and Mawas, we must still admit that a special element found in the serum gives to the exudates a special character which makes them lasting.

Even this again has brought us to admit the existence of special pathological elements present in the blood. But whilst for Bailliart these are of renal origin, we believe that various products will play the same rôle among which eventually we could count those of nephritic origin. It is worth while to note that Kollert found in the cases with neuroretinitis and malignant hypertension, an increase in blood fibrinogen, and of the sedimentation of erythrocytes.

How should we explain that among the various exudative phenomena described, the picture of Bright's neuroretinitis is so characteristically constant? Probably this is due to the constant presence of the same metabolic troubles, which are at the basis of the whole syndrome of retinitis and nephritis and have a constant and characteristic way of affecting the retina and the vessels.

In fact, the pictures of the different neuroretinitides are much alike. Some authors have tried to see sufficient differences to establish an aetiological classification based on ophthalmoscopic appearance. Especially have arteriosclerotic forms been isolated from the usual toxic forms. (Foster Moore.) But such distinctions are still uncertain, and we have not yet decided if the retinitis of diabetes has really its individuality, and a true constant characteristic picture, as opposed to the albuminuric forms.

We should rather admit with Duke-Elder*: "In a tissue so highly differentiated as the retina, it is only to be expected that different toxins acting upon it would produce pathological alterations of a closely related type, the nature of which would be determined rather by the structure itself than by the causal agent. At the same time it is reasonable to suppose that the deficient circulation in arteriosclerosis may tend to introduce differentiating peculiarities, and that in diabetes the upset in the water balance... should be able to influence in a similar manner the backward

* W. Stewart Duke-Elder.-Recent Advances in Ophthalmology. Second Edition, p. 244. London: J. \& A. Churchill. 1929. 
continuation of the posterior epithelial layer in the retina, endowing on occasion the manifestations of the disease in this tissue with clinical characteristics of its own." In the same manner we could admit that the particular conditions presiding over the production of Bright's disease would give the particularities of the clinical picture.

The existence of different toxic processes all of which cause a retinal lesion (among which are included those due to Brightism), would explain the variable prognosis in different cases. We know that the prognosis of true Bright's neuroretinitis was considered very grave, quo ad vitam. On the contrary the pseudonephritic forms do not menace life and their local evolution is generally favourable. Latterly, even the prognosis of nephritic neuroretinitis seems less grave than it was considered before.

Among his 85 patients, Kollert found seven with a duration of over 2 years. One of these had a history of 10 years, and the others $8,7,5$ and 4 years respectively. He thinks that the bad prognosis is connected with a permanent hypertension, and if this tends to return to normal in the evolution of the disease, the prognosis becomes better. This shows that the prognosis is a function of the intensity of the general trouble and that even in nephritis this is not always so bad as to lead to early death.

We could not, unfortunately, follow up all the 35 cases of neuroretinitis over a long period. We have, however, a case of 7 years' duration in which the retinal signs have disappeared and the visual acuity has increased to 1 . Another patient is also alive 8 years after the diagnosis of neuroretinitis was made, notwithstanding marked hypertension (24/17 at the time of the first examination), which has continued till to-day. This might show that even hypertension alone is not always a true index for the prognosis.

The relatively severe prognosis of Bright's neuroretinitis shows at any rate the seriousness of the general trouble in Brightism. If this happens to recede, or to remain unprogressive the lesions of neuroretinitis themselves do not seem to be more persistent than in the other exudative forms. The resorption of the eclamptic forms, the periodicity of those in pregnancy, even the close observation of the other cases, show that there is the same tendency to heal. Brightism remains a very serious disease and even if we can treat it better to-day and give it a milder prognosis, it will be still far from the benignity of the other causes of neuroretinitis, and the appearance of this, in the course of nephritis remains a proof that the disease is progressing in a menacing way, and that the patient is in danger quo ad vitam.

Summary.-Retinitis pseudo-albuminurica stellata (among which we class our three cases given in this paper) occupies an 
intermediary position, as a transition between the typical Brightic forms and the different exudative ones, as described by Junius and Horniker. Their study gives us a better understanding of the pathogenesis of Bright's neuroretinitis, suggesting to us a similar mechanism in the production of the lesions.

The different aetiological factors acting on the retina (acute or chronic infectious diseases, cranial traumata, cerebral tumours, serous meningitis) determine (probably through a vascular mechanism) their related pictures, which represent somewhat the special kind of reaction of the retina, and differ in details according to the different cases and aetiologies. At the origin of the pseudoBrightic retinitis, due to intra-cranial tumour, there seems to be at mechanical lymph stasis, causing the papillary oedema and through it metabolic troubles. At the origin of the pseudo-Brightic, infections, etc., retinitis the local troubles seem under the dependence of general metabolic processes. All follow thereafter a similar evolution and produce related fundus pictures.

The neuroretinitis of nephritics is not connected by any causal link with the kidney lesions and therefore the only justified name should be that of Bright's neuroretinitis (understanding Brightism as a general disease, with renal, ocular and general manifestations.)

From the facts discussed here, we incline to admit that the production of the neuroretinitis is independent of arterial hypertension, which like the renal lesions, is only a symptom in evolution under the influence of the same causes.

The difference in evolution and prognosis between the Brightic forms and the so-called pseudonephritic is due to their different aetiology and to the intensity with which this affects the general state. This explains the benignity of those due to local processes and on the contrary the gravity of those where the whole organism is participating (hypertension, Brightism).

The characteristic clinical picture of Bright's neuroretinitis, shows that the special metabolic trouble, which forms its basis, has in its nature intensity and distribution of vascular action, particular and constant characteristics.

We think it might be of interest to group in a general table the observations we have discussed. 
Retinitis Pseudo-Nephritica Stellata

713

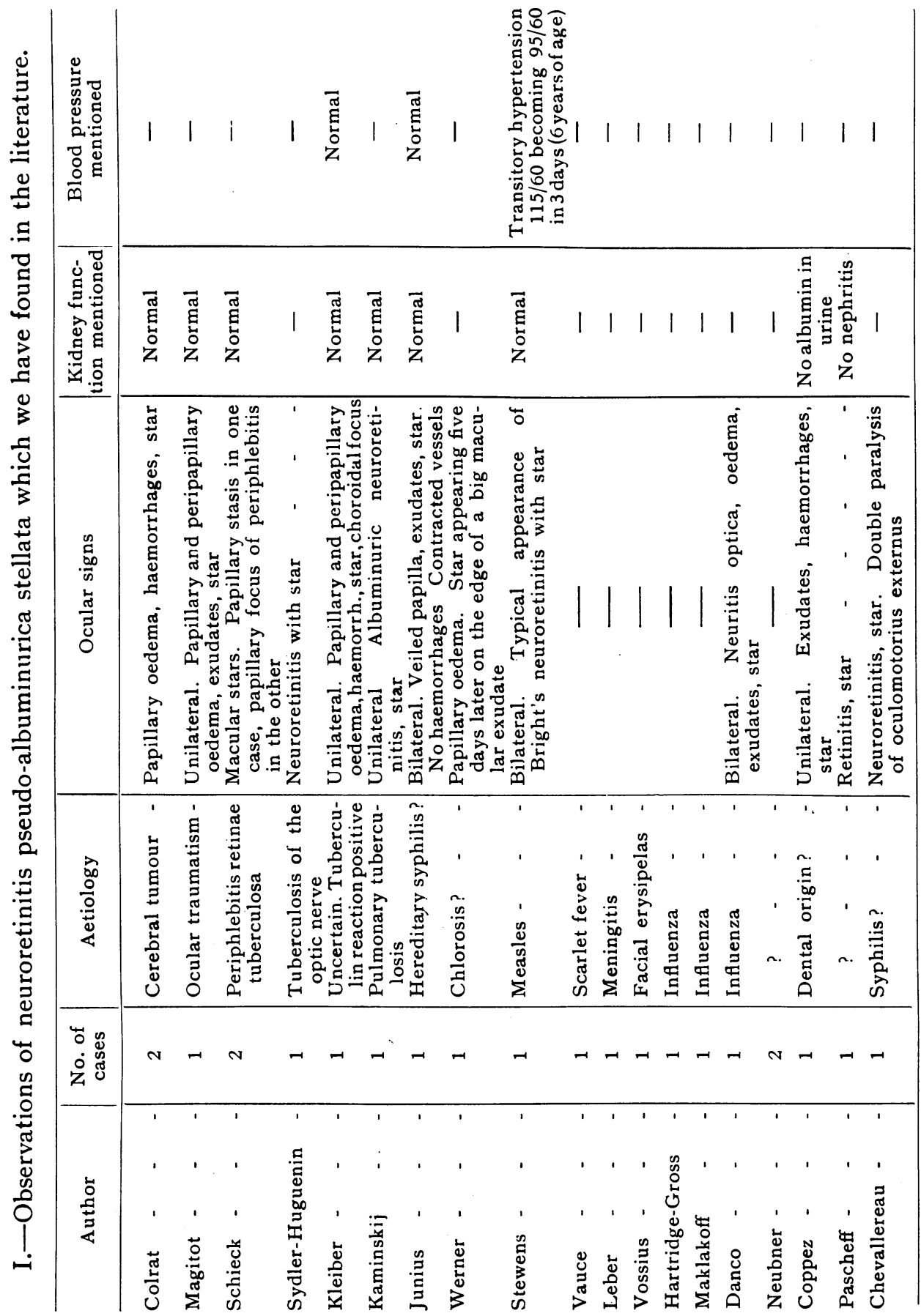

윰

흠웋

긍

ญั

혹

름

흥.

물.

옳

웅

을

N

:

证

$\stackrel{0}{\mathbb{D}}$ 
The British Journal of Ophthalmology
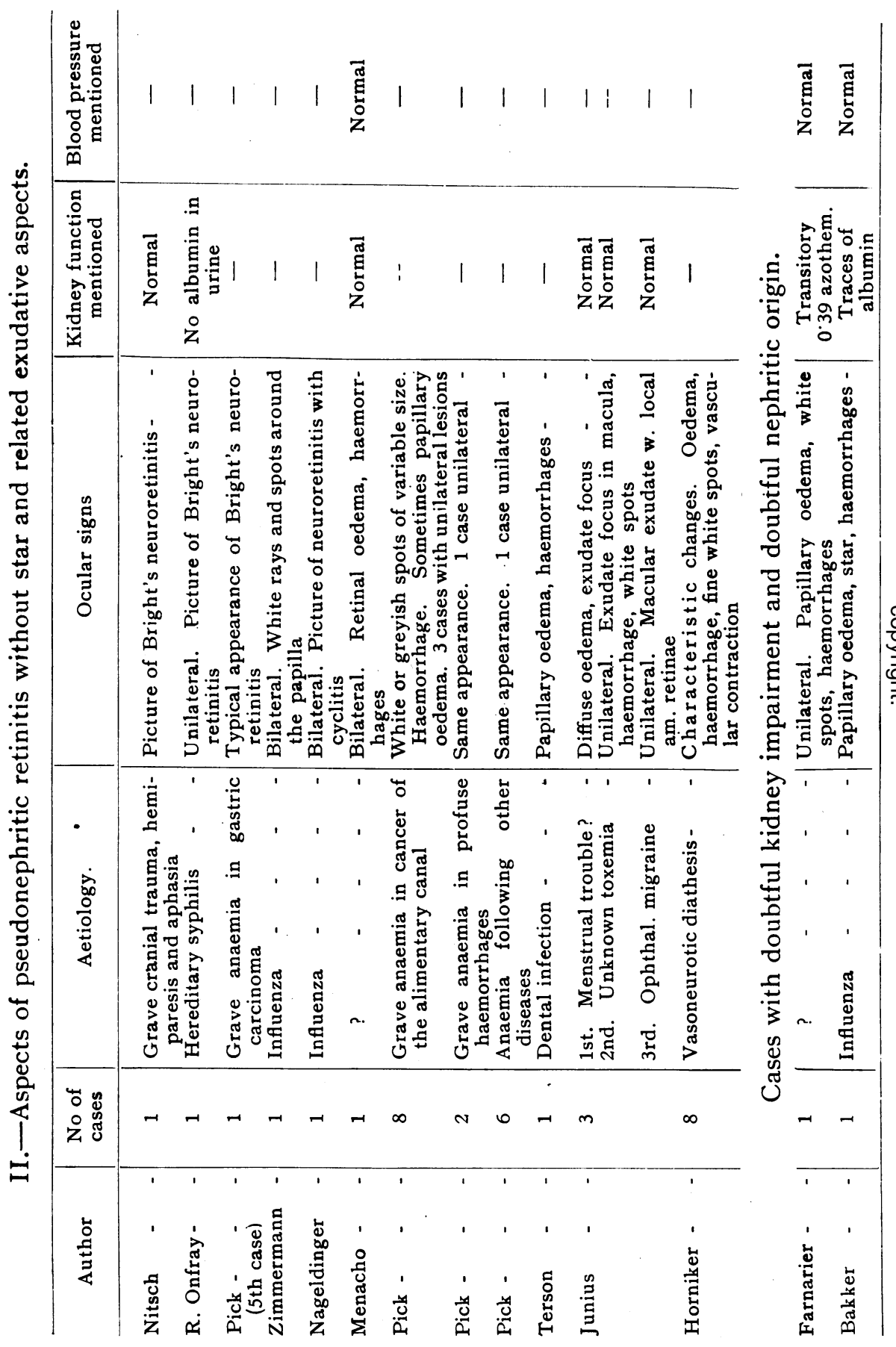

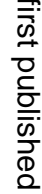




\section{BIBLIOGRAPHY}

1. Abelsdorf.-Pathogenese der Stauungspapille. Handbuch d. sp. patho. Anat., Henke, Lubarsch Auge, I Teil, p. 743.

2. Ambard.-Soc. d'Ophtal. de l'Est de France, 1929. In Terrien et Renard. Loc. cit.

3. Aschoff.-Versamm. Ges. Deutsch. Naturf. u. Aertzte, Hamburg, 1928. Quoted in Zentralbl. f. de ges. Ophthal., Vol. XX, p. 627, 1928.

4. Augstein.-Einseitig Papilloretin. mit ausserordentlich grosse Sternfigur bei Chlorose. Klin. Monatsbl. f. Augenheilk., Vol. LXIII, p. 174, 1919.

5. Bailliart. - La circulation rétinienne. 1923.

6. Bakker.-Ein Fall v. Neuroretinitis mit Sternfigur nach einer akuten Infectionskrankheit. Quoted in Zentralbl. f. d. ges. Ophthal., Vol. XXI, p. 254, 1929.

7. Barlow.-Fundus changes in hypertension with and without nephritis. Arch. of Ophthal., Vol. LVI, p. 356, 1927. Quoted in Zentralbl. f. d. ges. Ophthal., Vol. XIX, p. 90; 1928.

8. Behr.-Zur Entstehung der Stauungspapille. Arch.f. Ophthal., Vol. CI, $2 / 3 \mathrm{H}$, p. $165,1920$.

9. Chabanier, Loboonell.-De la rétinite dite albuminurique dans ses rapports avec l'insuffisance sécrétoire del reins. Presse Méd., p. 113, 1924.

10. Charlin, Loboonell.-El Pathogenesis del Retin. Album. Arch. de Oftal. Hisp.-Amer., Vol. XXVII, p. 429, 1927. Quoted in Zentralbl. f. d. ges. Ophthal., Vol. X[X, p. 91, 1928.

11. Chevallereau, Chaillous.- Sur une forme de neurorétinite d'origine centrale. Soc. d'Ophtal. de Paris, December, 1903. Quoted by Colrat.

12. Colrat.-Pséudorétinite stellaire et oedème papillaire dans les hypertensions intra-craniennes par tumeur. Arch. d'Ophtal., Vol. XLVII, p. 773, 1930.

13. Coppez.-Rétinite d'aspect albuminurique. Soc. belge. d'Ophtal. Arch. d'Ophtal., Vol. XLI, p. 113, 1924.

14. De la Fontaine Vervey.-Ueber die Arteriosclerose der Netzhaut und die Bedeut. f. die Genese der Retinitis. Klin. Monatsbl. f. Augenheilk., Vol. LXXIX, p. 148, 1927.

15. De Logu - Retinite albuminurica bilaterale avente in un occhio l'aspetto di retinite circinata atipica. Boll. d'Ocul., 1927. Quoted in Zentralbl.f.d. ges. Ophthal., Vol. XIX, p. 491, 1928.

16. Danco.-Ueber doppelseitige Neuroretinitis stellata nach Grippe. Klin. Monatsbl. f. Augenheilk, Vol. LXVII, p. 87, 1921.

17. Fahr.-Vers. Ges. deutsch. Natur. u. Aertzte, Hamburg, 1928. Quoted in Zentralbl.f. d. ges. Ophthal., Vol. XX, p. 627, 1928.

18. Farnarier. - Néurorétinite unilaterale dans un cas d'azothémie minime. Guerison. Ann. d'Ocul., Vol. CLXIV, p. 209, 1927.

19. Fileti.-Sulle alterazioni oculari nell' anemia pernic. Ann. di Ottal., 1927. Quoted in Zentralbl. f. d. ges. Ophthal., Vol. XIX, p. 27, 1928.

20. Hansen.-Zur Frage der Retinitis nephritica. Klin. Monatsbl.f. Augenheilk., Vol. LXXXII, p. 40, 1929.

21. Horniker. - Su di una forma die retinite centrale di origine vasoneurotica. Ann. di Ottal., Vol. LV, p. 865, 1927.

22. Zur Frage der Retinitis nephritica. Klin. Monatsbl.f. Augenheilk., Vol. LXXXII, p. 336, 1929.

23. Junius.-Erscheinungsformen und Ablauf der juven. Retin. exud. Macul. Zeitschr. f. Augenheilk., Vol. LXX, p. 129, 1930.

24. Kahler, Salman.--Les alter. de la. rétine dans les af. ren. et vascul, Zeitschr. f. Augenheilk., 1925. Quoted in Ann. d'Ocul., Vol. CLXV, p. $607,1928$.

25. Kalt.-Rétinite exudative sans altér. vasc. Bull. Soc. Ophtal. de Paris, Vol. IX, 1929. Quoted in Arch. d'Ophtal, Vol. XLVII, p. 320, 1930.

26. Kaminskij.-Zur Aetiologie der Retin. stellata seu pseudoalbum. Quoted in Zentralbl. f. d. ges. Ophthal., Vol. XXII, p. 298, 1929.

27. Kirieleis.-Retinitis albuminurica ohne ophthalmoscopisches Befund. Arch. f. Augenheilk., 1929. Quoted in Zentralbl.f.d.ges. Ophthal., Vol. XXII, p. $457,1929$.

28. Kleiber.-Ein Fall pseudonephritischer Retinitis stellata. Zeitschr. $f$. Augenheilk., Vol. LXX, p. 187, 1930. 
29. Kollert. - Entstehungs u. Heilungsbedingungen der Retin. nephritica. , Zeitschr. f. klin. Med., 1927. Quoted in Zentralbl. f.d.ges. Ophthal., Vol. XIX, p. 488, 1928.

30. Koyanagy.-Ueber die Pathogenese der Retin. neph. Klin. Monatsbl. f. Augenheilk., Vol. LXXX, p. 436, 1928.

31. Ueber das Zustandekom. des ophthalmoscopischen Befunds bei Chorioretinitis nephr. Klin. Monatsbl. f. Augenheilk., Vol. LXXXIV, p. $737,1930$.

32. Leber.-Ueber die Entstehungsweise der nephritischen Netzhautkrankh. Arch. f. Ophthal., Vol. LXX, p. 200, 1909.

33. Levinsohn.--Kurze Bemerkungen zur Pathogenese der Stauungspapille. Arch. f. Ophthal., Vol. CXXIII, 1 H, p. 34, 1929.

34. Levy, Yolande.-De la pathogenie de la rétinite albuminurique. Strabis. Medic., Vol. LXXXV, p. 237, 1927. Quoted in Zentralbl. f. d. ges. Ophthal., Vol. XIX, p. 238, 1928.

35. Lo Cascio.-Recherches cliniques anat. pat. et pathog. sur la neurorét. albumin. Ann. di Ottal., Vol. LIV, pp. 1 et 129, 1925.

36. Lo Russo.-La rétinite diabetica. Ann. di Ottal., Vol. LV, p. 222, 1927.

37. Magitot.-Rétinite unilatérale du type azothem. sans azothémie. Bull. Soc. Ophtal. de Paris, 1930. Quoted in Zentralbl.f. d. ges. Ophthal., Vol. XXIII, p. 284, 1930.

38. Discussion sur la stase papillaire. Soc. Fr. Ophtal.; Ann. d'Ocul., Vol. CLXVI. p. 409, 1929.

39. Marx, Hellmuth. - Schmidt. Akuter Morbus Brighti mit Retinitis ohne Nephritis. Deutsch. Med. Wochenschr., p. 909, 1928.

40. Menacho.-Retinitis haematovascularen Ursprungs. Arch. de Oftal. Hisp.Amer., 1927. Quoted in Zentralbl. f. d. ges. Ophthal., Vol XVIII, p. $255,1927$.

41. Milius.-Versamm. Gesel. Deutsch. Nat. u. Aertzte. Hamburg, 1928. Quoted in Zentralbl. f. d. ges. Ophthal., Vol. XX, p. 627, 1928.

42. Minich.-Zur Kenntniss der, im Verlaufe der pernic. Anaem. beobachtete Spinalerkr. Zeitsch. f. klin. med Quoted in Pick, loc. cit.

43. Nageldinger.-Pséudorétinite albuminurique compliquée de cyclite. Bull. Soc. Ophtal. de Paris. Quoted in Zentralbl. $f$. d. ges. Ophthal., Vol. XIX, p. 238, 1928.

44. Nitsch.-Rétinite pseudoalbum. avec trou dans le macula après un traumatisme cranien. Zeitschr. f. Augenheilk, 1924. Abstracted in Ann. d'Ocul., Vol. CLXIV, p. 802, 1927.

45. Onfray, Margerin. - Pséudorétin. albumin. chez un enfant bérédosyphíl. Arch. d'Ophtal, Vol. XL, p. 635, 1923.

46. Pascheff.-Rétinite stellaire transitoire. Soc. d'Ophthal, Heidelberg, 1928. Abstract in Ann. d'Ocul., Vol. CLXVI, p. 154, 1929.

47. Paton and Holmes.-The pathology of papilloedema. Brain, Vol. XXXIII, p. $389,1911$.

48. Pick.-Netzhautveränderungen bei chronischen Anämien. Klin. Monatsbl.f. Augenheilk., Vol. XXXIX, p. 177, 1901.

49. Poyales.-Der Kreatininindex im Blut. Arch. de Oftal. Hisp.-Amer., 1927. Quoted in Zentralbl.f. d. ges. Ophthal., Vol. XIX, p. 338. 1928.

50. Puscariu et J. Nitzulescu.-Considerations sur la pathogenie de la néurorétinite nephrétique. Ann. d'Ocul., Vol. CLXIV, p. 16, 1927.

51. Rochon-Duvigneaud.-Rapport à la Soc. Fr. d'Ophtal., 1912.

52. Roth.-Vilchow's Arch.f. path. Anat., Vol. LV, 1872. In Pick, loc. cit.

53. Schieck.-Die Pathogenese der Retinitis albúminurica. Zentralbl.f.d. ges. Ophthal., Vol. XXI, p. 1, 1929.

54. Kurzes' Handbuch der Ophthal., Vol. V, p. 448, 1930.

55. Spalding, Curtis.-Retinitis and other changes in the eyes of diabetics. Boston Medic. and Surgic. Jl., Vol. CXCVII, p. 165, 1927.

56. Stewens.-Neuroretinitis nach Masern. Klin. Monatsbl. f. Augenheilk., Vol. LXXXIV, p. 714, 1930.

57. Sydler, Huguenin, in Scheick's Handb. der.Ophthal!, Vol. V, p. 448.

58. Terrien, Renard.-Remarques sur les rétinites dites azothémiques. Arch. d'Ophtal., Vol. XLVI, p. 594, 1929.

59. Volhard.-Die Pathogenese der Retinitis albuminurica. Zentralbl.f.d. ges. Ophthal., Vol. XXI, p. 129, 1929.

60. Wagener.-The retinitis of malignant hypertension. Trans. Amer. Ophthal. Soc., Vol. XXV, p. 349, 1927. Quoted in Zentralbl.f.d.ges. Ophthal., Vol. XX, p. $362,1928$. 